УДК 378.041:51-028.77(045)

DOI:

Лариса Фоменко, викладач кафедри математики та фізики Комунального закладу “Харківська гуманітарно-педагогічна академія” Харківської обласної ради

\title{
РЕЗУЛЬТАТИ ПЕДАГОГІЧНОГО ЕКСПЕРИМЕНТУ $З$ РОЗВИТКУ ПІЗНАВАЛЬНОЇ АКТИВНОСТІ МАЙБУТНІХ УЧИТЕЛІВ ІНФОРМАТИКИ У ПРОЦЕСІ МАТЕМАТИЧНОЇ ПІДГОТОВКИ
}

У статті порушено проблему розвитку пізнавальної активності майбутніх учителів інформатики. Метою статті є подання результатів педагогічного експерименту щодо перевірки ефективності теоретично обтрунтованої та розробленої технології розвитку досліджуваної якості в процесі математичної підготовки. Охарактеризовано етапи педагогічного експерименту, критерії $і$ показники, а також методики їх дослідження. Здійснено аналіз результатів констатувального й контрольного етапів педагогічного експерименту й наведено динаміку змін рівнів розвитку пізнавальної активності в контрольній та експериментальній групах.

Ключові слова: педагогічний експеримент; пізнавальна активність; майбутні вчителі інформатики; розвиток; розвиток пізнавальної активності; математична підготовка.

Puc. 1. Jim. 5.

Larysa Fomenko, Lecturer of the Mathematics and Physics Department of Municipal Establishment Kharkiv Humanitarian Pedagogical Academy of Kharkiv Regional Council

\section{THE RESULTS OF THE PEDAGOGICAL EXPERIMENT ON THE DEVELOPMENT OF FUTURE COMPUTER SCIENCE TEACHERS' COGNITIVE ACTIVITY IN MATHEMATICAL TRAINING}

The article deals with the problem of development of the future computer science teachers' cognitive activity. Emphasis is placed on the importance of mathematical training as a component of professional training of students of specialty 014.09 Secondary Education (Computer Science). The concept of "cognitive activity of the future computer science teacher" is defined and the structure of the investigated quality is given. It is proposed to introduce pedagogical technology in the mathematical training for the development of the future computer science teachers, cognitive activity, which consists of three interconnected components (methodological and purposeful, organizational and technological and diagnostic) and is implemented in stages (preparatory-informational (involves designing and refining the technology of development of the future computer science teachers' cognitive activity in the mathematical training), activity-effective (involves practical implementation of the developed technology by the components of cognitive activity (motivational, cognitive-research, personal-reactive), control-regulatory (involves finding out the effectiveness of the technology of investigated quality development)). The stages of pedagogical experiment (ascertaining, forming, controlling), which was conducted in order to check the effectiveness of the developed technology, are characterized. The criteria (motivational, cognitive-research, personality-reflective) and corresponding indicators, which were used to diagnose the level of development of the future computer science teachers' cognitive activity at the ascertainment and control stages of pedagogical experiment, as well as the methods of their research, are explained. The results of the ascertaining and control stages of the pedagogical experiment are analyzed and the dynamics of changes in the levels of development of cognitive activity in the experimental and control groups is presented. In particular, it was shown that the level of development of cognitive activity in the experimental group after the experiment significantly increased compared with the control group, which indicates the effectiveness of the developed technology.

Keywords: pedagogical experiment; cognitive activity; future computer science teachers; development; development of cognitive activity; mathematical training.

$\Pi$ остановка проблеми. Потреба у розвитку пізнавальної активності майбутніх учителів інформатики значно зростає у зв’язку необхідністю постійно відстежувати зміни й тенденції розвитку цифрових технологій, опановувати нові програми та сервіси, творчо застосовувати отримані знання у професійній діяльності й передавати їх дітям, допомагати колегам запроваджувати нові інформаційні технології в освітній процес. Саме тому вважаємо, що розвиток пізнавальної активності має бути однією із важливих складових професійної підготовки майбутніх учителів інформатики, невід'ємною частиною 


\section{РЕЗУЛЬТАТИ ПЕДАГОГІЧНОГО ЕКСПЕРИМЕНТУ 3 РОЗВИТКУ ПШЗНАВАЛЬНОЇ АКТИВНОСТІ МАЙБУТНІХУЧИТЕЛІВ ІНФОРМАТИКИУ ПРОЦЕСІ МАТЕМАТИЧНОӤ ПІГОТОВКИ}

освітнього процесу у закладах вищої педагогічної освіти.

Важливою складовою фундаментальної підготовки майбутніх учителів інформатики виступає математична підготовка, яка сприяє не лише загальному інтелектуальному розвитку особистості, а й оволодінню методами математичного моделювання, оптимізації, прогнозування, кількісного та якісного аналізу, збору та обробки інформації. Математична підготовка має значні потенційні можливості для розвитку пізнавальної активності майбутніх учителів інформатики, однак, в закладах вищої освіти ці можливості не використовуються повною мірою.

Аналіз останніх досліджень і публікацій. Проблемою розвитку пізнавальної активності особистості у різні часи займалися К. АбульхановаСлавська, Л. Аристова, Ю. Бабанський, Л. Виготський, О. Леонтьєв, В. Лозова, П. Лузан, М. Махмутов, О. Пиндик, Н. Тализіна, Т. Хоменко, Г. Щукіна та ін. Окремим питанням розвитку пізнавальної активності майбутніх учителів присвячено праці Т. Алексєєнко, А. Воєводи, О. Сгорової, Л. Левчук, Л. Мамедлі, Л. Мачушник, В. Молчанової, Д. Соменка, О. Соменко та ін. Багато уваги дослідники (Ю. Горошко, Л. Гризун, М. Золочевська, Ж. Кожухар, Г. Монастирна, І. Морквян, С. Семеріков, О. Спірін, А. Харківська, В. Шовкун та багато інших) присвячують проблемам професійної підготовки майбутніх учителів інформатики у закладах вищої освіти, зокрема математичній підготовці як важливій складовій професійної підготовки майбутніх учителів інформатики (Т. Армаш, М. Бакланова, О. Грицюк, Г. Дутка, В. Єфименко, В. Клочко, О. Кучерук, І. Лов'янова, С. Раков, С. Рендюк, Ю. Триус, Д. Щедролосьєв та інші). Проте, проблема розвитку пізнавальної активності майбутніх учителів інформатики, зокрема під час вивчення математичних дисциплін, ще недостатньо досліджена як у теоретичному, так і в методичному аспектах.

Метою статті є представлення результатів педагогічного експерименту щодо перевірки ефективності технології розвитку пізнавальної активності майбутніх учителів інформатики в процесі математичної підготовки.

Виклад основного матеріалу дослідження. Пізнавальна активність є важливою умовою формування у студентів потреби в знаннях, оволодіння вміннями інтелектуальної діяльності, самостійності, забезпечення глибини і міцності знань, успішної підготовки до майбутньої професійної діяльності $[2,126]$. Під поняттям “пізнавальна активність майбутнього вчителя інформатики" розуміємо інтегративну якість особистості, що сприяє ефективній підготовці та здійсненню професійно-педагогічної діяльності, мета якої підпорядкована потребі особистості у пізнанні; виявляється в позитивному ставленні до змісту й процесу навчання, прагненні до самоосвіти, самовдосконалення, творчого зростання впродовж життя; спрямована на постійне відслідковування й опанування нових цифрових пристроїв та програм для подальшого ï застосування в освітньому процесі 33СО, заохочення учнів та колег використовувати нові інформаційні технології унавчальній та позанавчальній діяльності. В структурі пізнавальної активності майбутніх учителів інформатики виокремлюємо мотиваційний, когнітивно-дослідницький та особистіснорефлексійний компоненти [5].

Для розвитку пізнавальної активності майбутніх учителів інформатики в процесі математичної підготовки нами розроблено педагогічну технологію, запровадження якої в процес закладів вищої педагогічної освіти, які готують фахівців зі спеціальності 014.09 Середня освіта (Інформатика), яка складається 3 трьох взаємопов'язаних компонентів (методологічноцільового, організаційно-технологічного та діагностувального) та реалізується за етапами (підготовчо-інформаційним (передбачає проєктування й розробку технології розвитку пізнавальної активності майбутніх учителів інформатики в процесі математичної підготовки), діяльніснорезультативним (передбачає практичну реалізацію розробленої технології за компонентами пізнавальної активності (мотиваційним, когнітивнодослідницьким, особистісно-рефлексійним), контрольно-регулятивним (передбачає з'ясування ефективності технології розвитку досліджуваної якості).

Перевірка ефективності розробленої технології розвитку пізнавальної активності майбутніх учителів інформатики в процесі математичної підготовки здійснювалась під час спеціально організованого педагогічного експерименту, 3 урахуванням теоретичних основ проведення експериментальних досліджень у педагогіці, розкритих у роботах $[1 ; 3 ; 4]$.

Педагогічний експеримент проводився в природних умовах без порушення логіки й ходу освітнього процесу в три етапи: констатувальний (передбачав визначення критеріального апарату дослідження, розробку системи діагностування розвитку пізнавальної активності майбутніх учителів інформатики, здійснення “вхідного" вимірювання рівня розвитку досліджуваної якості 


\section{РЕЗУЛЬТАТИПЕДАГОГІЧНОГОЕКСПЕРИМЕНТУ 3 РОЗВИТКУ ПІЗНАВАЛЬНОЇ АКТИВНОСТІ}

МАЙБУТНІХУЧИТЕЛІВ ІНФОРМАТИКИ У ПРОЦЕСІ МАТЕМАТИЧНОЇПІДГОТОВКИ

й розподіл студентів на експериментальні та контрольні групи), формувальний (передбачав запровадження теоретично обгрунтованої й розробленої технології розвитку пізнавальної активності майбутніх учителів інформатики в процесі математичної підготовки), контрольний (передбачав проведення контрольного вимірювання рівня розвитку пізнавальної активності майбутніх учителів інформатики в експериментальній і контрольній групах; здійснення аналізу й порівняння результатів, які були отримані на констатувальному та контрольному етапах експерименту; перевірку й підтвердження значущості результатів експерименту за допомогою методів математичної статистики).

Для визначення рівня розвитку пізнавальної активності майбутніх учителів інформатики на констатувальному й контрольному етапах експерименту було розроблено критерії та відповідні їм показники: мотиваційний (усвідомлення потреби в пізнанні нового, мотивація вдосконалення професійної підготовки через розвиток пізнавальної активності, наявність пізнавального інтересу у майбутніх учителі інформатики у процесі вивчення математичних дисциплін); когнітивно-дослідницький (якість теоретичних знань із математичних дисциплін; уміння акумулювати та творчо застосовувати набуті знання; уміння використовувати інформаційно-комунікаційні для розвитку пізнавальної активності в процесі вивчення математичних дисциплін); особистіснорефлексійний (уміння планувати й організовувати власну пізнавальну діяльність, здатність до саморозвитку й самоосвіти в процесі математичної підготовки, здатність до рефлексії власної пізнавальної активності). Урахувавши, що початковий рівень пізнавальної активності в студентів має бути сформований під час отримання загальної середньої освіти, визначено три рівні розвитку досліджуваної якості - середній, достатній та високий.

Діагностика рівнів розвитку пізнавальної активності майбутніх учителів інформатики здійснювалась за допомогою анкетування (анкета “Прагнення вдосконалення професійної підготовки через розвиток пізнавальної активності майбутніх учителів інформатики у процесі вивчення математичних дисциплін”, анкета щодо визначення рівня здатності майбутніх учителів інформатики до саморозвитку й самоосвіти в процесі математичної підготовки), тестування (тест для визначення наявності пізнавального інтересу у майбутніх учителів інформатики в процесі вивчення математичних дисциплін, тест для виявлення рівня володіння комп'ютерною технікою та інформаційно-комунікаційними технологіями), опитування (опитувальник для визначення рівня розвитку пізнавальної потреби студентів у процесі вивчення математичних дисциплін, опитувальник для визначення здатності майбутніх учителів інформатики до планування й організації власної пізнавальної діяльності; опитувальник для виявлення рівня здатності до здійснення рефлексії), вивчення результатів навчальних досягнень (семестрових оцінок та ректорських контрольних робіт із математичних дисциплін; оцінок із проходження різних видів практики) майбутніх учителів інформатики тощо.

У педагогічному експерименті взяли участь 142 осіб. Серед них - студенти (124 особи) та викладачі закладів вищої педагогічної освіти (18 осіб). Експериментальна група (ЕГ) налічувала 62 студента, навчання яких відбувалося за розробленою технологією розвитку пізнавальної активності майбутніх учителів інформатики в процесі математичної підготовки. Контрольна група (КГ) складалася із 62 студентів, які навчалися за традиційними навчальними планами та методиками підготовки.

На констатувальному етапі педагогічного експерименту респонденти експериментальної та контрольної груп мали статистично однаковий рівень пізнавальної активності, причому переважна більшість студентів як у експериментальній, так і в контрольній групах перебували на достатньому (35,5\% та $34 \%$ відповідно) та середньому $(56,5 \%$ та $58 \%$ відповідно) рівнях. Це обумовлено тим, що більшість студентів не в достатній мірі усвідомлюють потребу в збагаченні новими знаннями, не приділяють достатньо уваги виконанню додаткових завдань, навчаються заради отримання диплому про вищу освіту, не проявляють наполегливості й рішучості, коли виникають труднощі у навчанні. Цим підтверджується необхідність запровадження технології розвитку пізнавальної активності майбутніх учителів інформатики в процесі математичної підготовки.

Під час формувального етапу педагогічного експерименту відбувалося запровадження розробленої технології в експериментальній групі за відповідними етапами, а саме: підготовчоінформаційним, діяльнісно-результативним, контрольно-регулятивним.

На підготовчо-інформаційному етапі проводилася робота 3 викладачами щодо підготовки їх до упровадження розробленої технології (ознайомлення викладачів зі змінами в 


\section{РЕЗУЛЬТАТИПЕДАГОГІЧНОГО ЕКСПЕРИМЕНТУ 3 РОЗВИТКУ ПІЗНАВАЛЬНОЇ АКТИВНОСТІ МАЙБУТНІХУЧИТЕЛІВ ІНФОРМАТИКИ У ПРОЦЕСІ МАТЕМАТИЧНОЇ ПІДГОТОВКИ}

змісті професійної підготовки майбутніх учителів інформатики; з формами, методами, прийомами, засобами, які будуть застосовуватись під час реалізації технології; з методами діагностики результатів упровадження технології та факторами оцінювання результатів роботи на різних етапах) та студентами спеціальності 014.09 Середня освіта (Інформатика) щодо підготовки їх до активної участі в процесі розвитку в них пізнавальної активності (ознайомлення студентів зі змістом, формами, методами, засобами, які будуть використовуватися під час реалізації педагогічної технології, а також із методами діагностики рівня розвитку в них пізнавальної активності в процесі математичної підготовки).

Метою діяльнісно-результативного етапу практичної реалізації розробленої технології було підвищення рівня розвитку пізнавальної активності майбутніх учителів інформатики в процесі математичної підготовки за компонентами пізнавальної активності (мотиваційним, когнітивнодіяльнісним, особистісно-рефлексійним). Зокрема, для розвитку: мотиваційного компоненту були проведені лекція-практикум “Активізація пізнавальної активності студентів при вивченні математики”, тренінг “Стратегії підвищення мотивації майбутніх учителів інформатики у процесі математичної підготовки"; когнітивнодослідницького - додаткові консультації 3 предметів математичного циклу; факультатив "Математичні дисципліни й розвиток пізнавальної активності майбутніх учителів інформатики"; особистісно-рефлексійного - факультатив “Саморозвиток та рефлексія майбутніх учителів інформатики у процесі вивчення математики", круглі столи “Стимулювання позитивного ставлення до математичної підготовки майбутніх учителів інформатики”, “Технології розвитку пізнавальної активності від школи до ЗВПО”, кафедральні телемости між студентами ЗВПО за загальною темою "Методологічні орієнтири розвитку пізнавальної активності майбутніх учителів інформатики у процесі вивчення математичних дисциплін” тощо.

Контрольно-регулятивний етап був спрямований на з'ясування ефективності технології розвитку пізнавальної активності майбутніх учителів інформатики у процесі математичної підготовки. Завданнями контрольно-регулятивного етапу було: збирання, аналіз, обробка та систематизація інформації щодо розвитку досліджуваної якості; контроль, який здійснювався протягом усіх етапів реалізації технології, що дозволило аналізувати ефективність запропонованих методик, форм, методів та засобів розвитку досліджуваної якості та вносити, у разі необхідності, відповідні зміни в освітній процес.

На контрольному етапі педагогічного експерименту було здійснено вимірювання рівня розвитку пізнавальної активності у респондентів ЕГ та КГ. На рисунку 1 наведено узагальнені результати проведеного дослідження.

На основі отриманих результатів можемо констатувати позитивну динаміку рівнів розвитку досліджуваної якості як в експериментальній, так і в контрольній групах. Однак, зазначимо, що в ЕГ, в якій запроваджувалась технологія розвитку пізнавальної активності в процесі математичної підготовки, відсотковий показник високого рівня

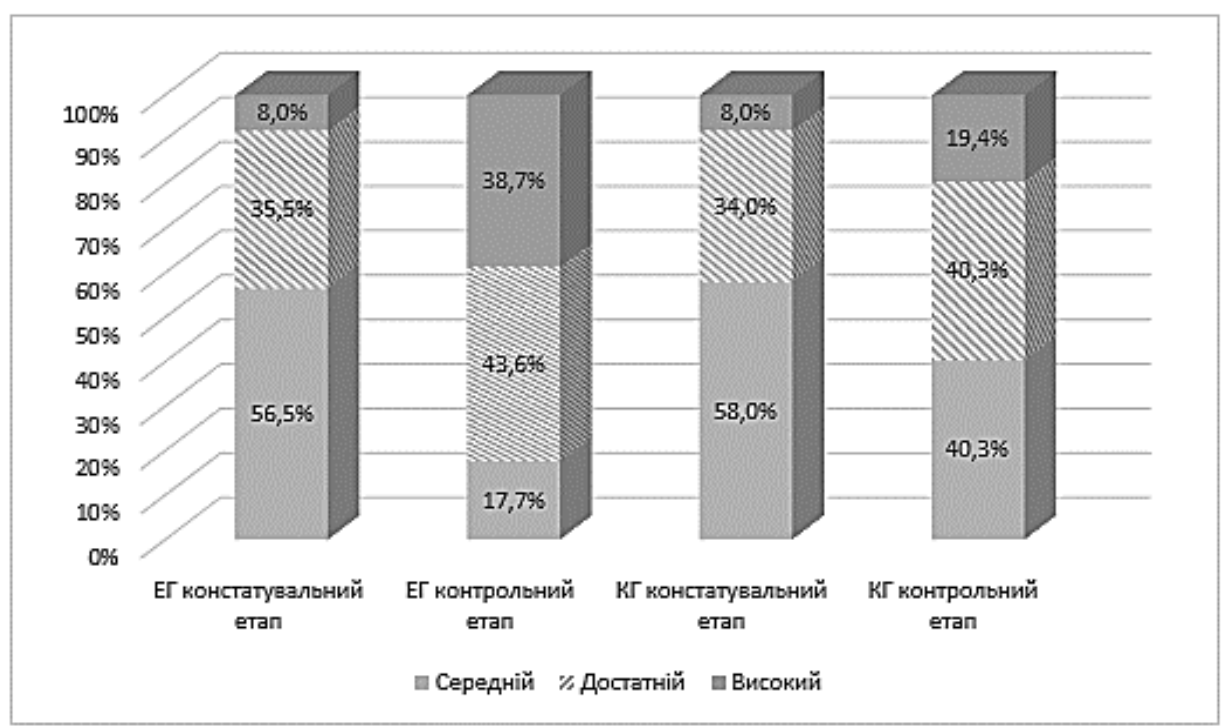

Рис. 1. Рівні розвитку пізнавальної активності майбутніх учителів інформатики в процесі математичної підготовки на констатувальному та контрольному етапах експерименту 
на контрольному етапі експерименту становить $38,7 \%$, що на 30,7 \% більше у порівнянні з результатами констатувального етапу в цій групі й на 19,3 \% більше, ніж відповідний показник у КГ в кінці експерименту. Відсотковий показник достатнього рівня в експериментальній та контрольній групах становить відповідно 43,6 \% (приріст $+8,1 \%$ ) та 40,3\% (приріст $+6,3 \%$ ). Відсотковий показник середнього рівня знизився в ЕГ до 17,7 \%, в КГ до 40,3 \%, причому різниця між динамічними показниками в ЕГ та КГ становить 21,1\%.

Висновки та перспективи подальших розвідок. Отже, на основі аналізу результатів експериментальної роботи можемо констатувати, що респонденти експериментальної групи мають переважно високий $(38,7$ \%) і достатній (43,6 \%) рівні розвитку пізнавальної активності. У контрольній групі переважають достатній (40,3%) і середній (40,3\%) рівні, що мало місце й на констатувальному етапі експерименту, хоча беззаперечно спостерігається позитивна динаміка, однак, приріст відсоткових показників $\epsilon$ значно меншим. Експериментальне дослідження свідчить про ефективність розробленої технології розвитку пізнавальної активності майбутніх учителів інформатики в процесі математичної підготовки, яка була реалізована за підготовчоінформаційним, діяльнісно-результативним й контрольно-регулятивним етапами й передбачала проведення лекції-практикуму “Активізація пізнавальної активності студентів при вивченні математики”, тренінгу Стратегії підвищення мотивації майбутніх учителів інформатики у процесі математичної підготовки", факультативів "Математичні дисципліни й розвиток пізнавальної активності майбутніх учителів інформатики" і “Саморозвиток та рефлексія майбутніх учителів інформатики у процесі вивчення математики”, додаткових консультацій 3 предметів математичного циклу, круглих столів “Стимулювання позитивного ставлення до математичної підготовки майбутніх учителів інформатики” та “Технології розвитку пізнавальної активності від школи до ЗВПО” тощо.

Перспективним напрямком дослідження залишається пошук нових методичних рішень щодо розвитку пізнавальної активності студентів спеціальності 014.09 Середня освіта

(Інформатика), а й інших спеціальностей.

\section{ЛІТЕРАТУРА}

1. Лодатко Є. О. Структурне моделювання педагогічного експерименту. Педагогічний проиес: теорія і практика. 2014. № 2. С. 5-9.

2. Повєткін С. В. Навчально-пізнавальна активність студентів молодших курсів та і1і сутність. Засоби навчальної та науководослідної роботи. 2012. Вип.39. С. 126-132.

3. Сисоєва С. О., Кристопчук Т. Є. Методологія науково-педагогічних досліджень : підручник. Рівне, 2013. 360 с.

4. Тверезовська Н. Т., Сидоренко В. К. Методологія педагогічного дослідження : навч. посіб. Київ, 2013. $440 \mathrm{c}$.

5. Фоменко Л. М. Пізнавальна активність майбутніх учителів інформатики: дефінітивний та структурний аналіз. Наукові записки Вінницького державного педагогічного університету імені Михайла Коцюбинського. Серія : Педагогіка і психологія. 2018. Вип. 55. С. 124-130.

\section{REFERENCES}

1. Lodatko, Ye. O. (2014). Strukturne modeliuvannia pedahohichnoho eksperymentu [Structural modeling of pedagogical experiment]. The pedagogical process: theory and practice, 2, pp. 5-9. [in Ukrainian].

2. Povietkin, S. V. (2012). Navchalno-piznavalna aktyvnist studentiv molodshykh kursiv ta yii sutnist [Educational and cognitive activity of junior students and its essence]. Means of educational and research work, 39, pp. 126-132. [in Ukrainian].

3. Sysoieva, S. O. \& Krystopchuk, T. Ye. (2013). Metodolohiia naukovo-pedahohichnykh doslidzhen [Methodology of scientific and pedagogical research]. Rivne, 360 p. [in Ukrainian].

4. Tverezovska, N. T. \& Sydorenko, V. K. (2013) Metodolohiia pedahohichnohodoslidzhennia[Methodology of pedagogical research]. Kyiv, 440 p. [in Ukrainian].

5. Fomenko, L. M. (2018) Piznavalna aktyvnist maibutnikhuchyteliv informatyky: definityvnyi ta strukturnyi analiz [The cognitive activity of future computer science teachers: definitive and structural analysis]. Scientific notes of Vinnytsia State Pedagogical University named after Mikhail Kotsyubynsky. Series: Pedagogy and Psychology, 55,pp. 124-130. [in Ukrainian].

Стаття надійшла до редакції 01.11.2019

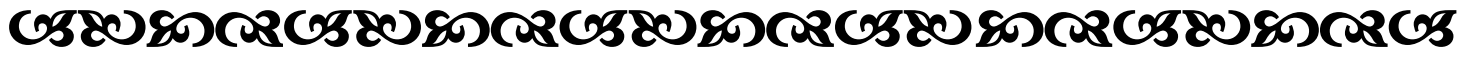

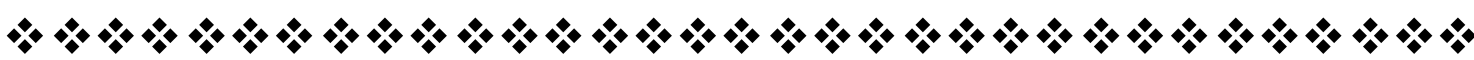

